\title{
Theory of Economy as the Original Cause of the World Crisis
}

\author{
Witold Jakóbik ${ }^{1}$
}

ABSTRACT

A growing debate around the active role played by the neoliberal ideology and the economy connected with it in the crisis development. The polarisation of researchers in this area is quite significant: starting from the negation of this role to its complete affirmation. This analysis is aimed at contributing to the aforementioned debate, putting forward the following hypothesis: historical development of mainstream economics and its influence, to a considerable extent, determined the outbreak of the large-scale crisis. In the analytic part, I look into some aspects of economic methodology, both orthodox and heterodox, taking my own position on the basis of important literature. Criticism of the traditional paradigm and a review of innovative trends in research do not show a straightforward road, however, which imposes a moderately optimistic outlook on the future, especially as regards the application value of the theory of economy.

KEY WORDS: $\quad$ global crisis, methodology of economy, traditional and new paradigm

JEL Classification: A11, B22, G01

${ }^{1}$ University of Finance and Management in Warsaw, Poland

\section{Introduction}

The literature is dominated by the opinion that economy does not develop evenly, going through periods of stagnation or even a crisis, and on other occasions, quite the opposite - through periods of accelerated development. At the same time, it would be difficult to prove that economic progress and changes in economic dynamics are synchronized. The situation is all the more complex due to the fact that even in periods of extending the scope and method of economy (its evolution towards heterodoxy), it is subject to attacks, which, however, are not always professional. This is what is happening now, when the world is rising from the global economic breakdown and connections between the economic theory and the development of

-

Corespondence concerning to this article should be addressed to: w.jakobik@wp.pl events are assessed in a thorough and strict manner. Apart from emotional and strongly ideological approaches, there are also the ones based on a sound, scientific base. In an attempt to order them, these approaches can be defined as technical and economic, nihilistic and historical.

The first of these actually disregards the influence of economic sciences on the onset and development of the crisis in the USA and, subsequently, in the world. Representatives of this approach (e.g. Taylor, 2009; Claessens, Dell'Ariccia, Igan \& Laeven, 2010; Laeven \& Valencia, 2010) think that technical phenomena played the decisive role among the causes of the crisis: expansive monetary policy, globalization of financial markets, unprecedented debt constituting the source of mortgage funding and their securitisation. Actually, the exposure of certain psychological traits of Investors - greed, underestimation of risk or herd behaviour, constitutes the only exception in this approach, as the 

sulted in economic experiments in Great Britain and the United States. However, mainstream theories truly flourished in their interaction with the third phase of globalization (especially in the 1990s and later), giving rise to quite new qualitative phenomena.

\section{Primary and secondary causes of the crisis}

The weaknesses of some research approaches presented above justify the application of the historical approach, the representatives of which analyze the formation of fundamental, primary causes of the global breakdown from a long-term perspective. The fact that, in the course of time, they have generated secondary causes, which directly initiated the symptoms of the global financial and economic crisis, are their characteristic features. Therefore, the first step in the research procedure included the determination of the structure of dependencies between these causes (Fig.1).

Figure 1. Dependecies between causes of the global crisis

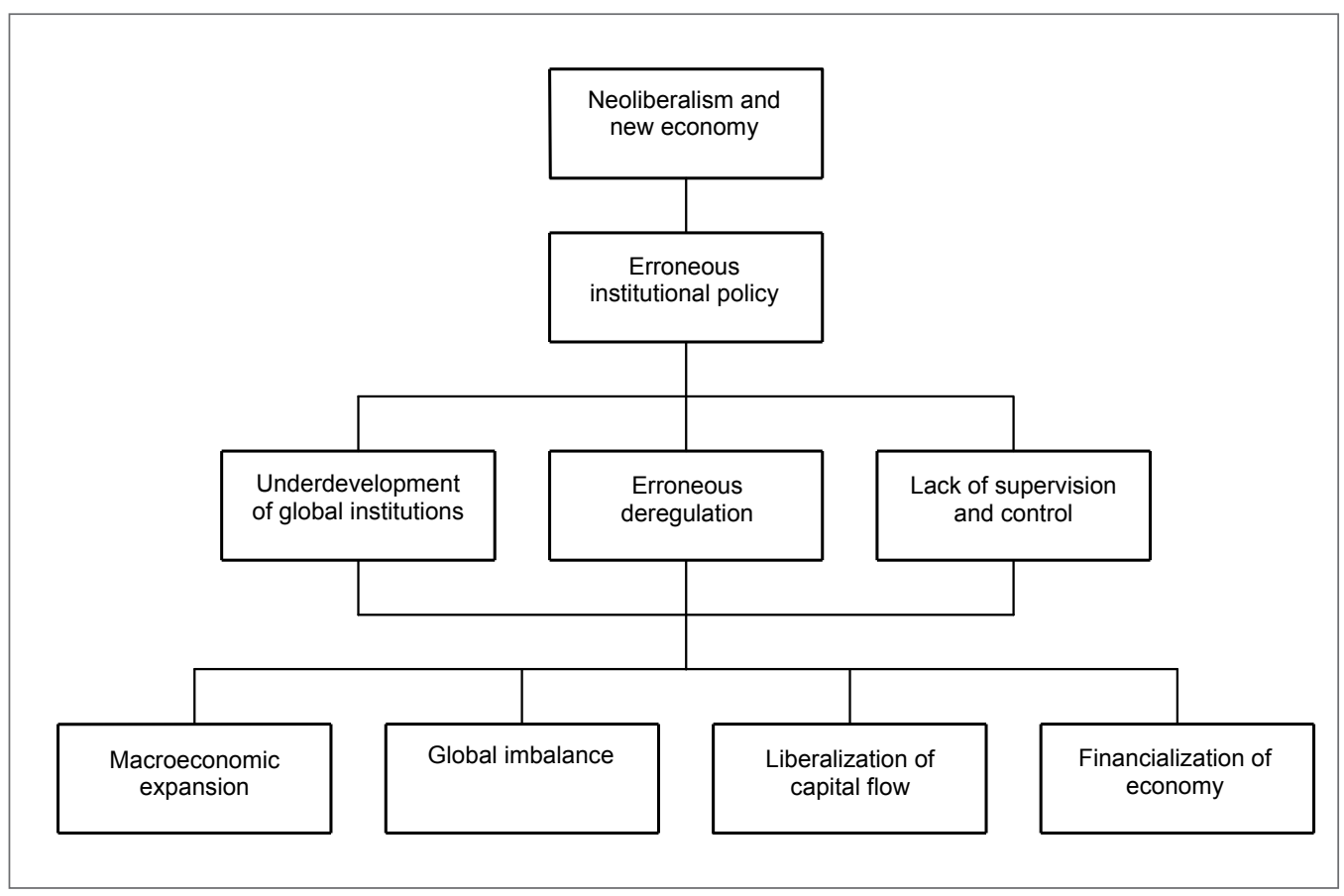

Source: Own study.

By adopting intellectual consideration as the primary cause of all economic events, it should be pointed out that liberalism constitutes the beginning of the future disputable, and as it will turn out, thought constructs. As it is known, it became part of the Enlightenment thought and it concerned political and economic conditions of social life (Hayek, 1982, p. 119). Classical economics developed on the liberal grounds and it created the institutional system enabling free activity of entities and at the same time, it made it possible to reach the economic and social optimum in the form of effective allocation of resources and fair division of income. However, in the course of time, liberalism, without losing its faith in the market and the freedom of the individual, evolved towards an idea of stressing the necessity of solving also social issues, which was reflected by, among other things, concepts of the protective state and social market economy.

Neoliberalism was not a consequence of linear development of liberalism; the former became a new 

model of regional and global modernisation, the national state (although its influence is limited) still takes care of the historical social and cultural identity, which has its place also in the world of economy. Culture, which is called global, does not have to be and is not Anglo-Saxon culture (or even Western culture) - it is rather a hybrid creation assimilating elements of various origins.

In summary, it can be stated that two tendencies, which are contradictory and, to some extent, have occurred at the present phase of globalisation: the positive base of the capital for institutionalisation falling within the neoliberal doctrine, and, simultaneously, conflicts between interests represented primarily by the main players, which made the institutionalisation process considerably more difficult. This brought about subsequent negative phenomena, which were connected with each other.

The first of these was called "systemic provisional measure" by Szymański (2009, pp. 30-31) or, in other words, incomplete globalisation. It means that a gap occurs in world institutions, there are no rules, which would regulate the behaviour of the individual countries as well as individual market participants (including corporations, banks, investment funds) in a sufficiently precise manner. Market economy on the global level does not have the supreme political authority or a set of legal regulations. This is just a step away from concluding that the existing provisional measure must come down to chaos, contractions, instability and crisis phenomena.

While agreeing with the author on his fundamental assessment of the aforementioned phenomena, a few critical remarks must be presented. Firstly, the term "systemic provisional measure" he used (does it refer to the institutional system?) appears to be too farreaching, especially in view of the existing articulation channels and clashes of interest on the international level. Secondly, both terms used by Szymański may lead to the false conclusion that it may be possible for humanity to arrive at some mature (institutional?) system and to ensure complete globalisation by establishing a global government, and, if not a global bank, then at least global coordination of the monetary policy (Rybiński, 2007) in the future. However, this will not be successful precisely because in social sciences, a diversity of modernity is accepted as well as numerous roads leading to it, so it will not be possible to build the so-called international community (Eisenstadt, 2001).

Erroneous deregulation was another phenomenon, which contributed to the outbreak of the global crisis, especially in the area of financial markets. The socalled first Basel I Capital Accord of 1987, which was aimed at forcing banks to limit the loan risk, is a paradoxical example here (Koronowski, 2009). In reality, however, it turns out to be erroneous deregulations as a result of a legal loophole in the Accord, American banks developed off-balance sheet transactions, i.e. items in derivative instruments and securitisation. Owing to the latter, lenders did not bother about loan repayment anymore.

More spectacular examples of erroneous deregulation also come from the American economy. The president of the Central Bank (Fed) Greenspan, who was the proponent of far-reaching freedom of financial markets, started to seek the abolition of the Glass-Steagall Act, which had been passed in 1933 by the Congress already held in 1987. This was aimed at eliminating pathologies of financial markets revealed during the Great Depression. Finally, the act was abolished in 1999. As a result, banks started to grant loans to profiteers and consolidation as well as mass securitisation of risky loans occurred. Unfortunately, these phenomena coincided with lack of supervision and control: some segments of the financial market did not need to be supervised, e.g. investment banks, rating agencies and the aforementioned off-balance sheet bank transactions primarily in the USA, but also in the Old Continent.

The beginnings of the difficult macroeconomic situation in the United States date back to the 2001 recession, when - after the unsuccessful reduction of success - the central bank, which is also responsible for production and employment, was forced to apply a negative real interest rate. This decision did make the investment demand of companies more dynamic; however, it also caused an increase in the mortgage debt of households refinancing it. This situation greatly increased the competition between non-bank financial institutions in the subprime market, which granted high-risk mortgage loans (Sławiński, 2007). The awareness of this fact made these institutions sell loans in the secondary market and these liabilities were, in turn, bought by securitisation funds belonging to banks. 

developed). In the latter, the capital, as a specific production factor is characterised by a higher final productivity and, so, altogether the world allocates its resources in a more effective way and ensures the optimal risk distribution, which results in a more intense economic growth. A conviction arose that free financial flows should bring visible effects, especially for countries poor in capital and, therefore, affected by excessive fluctuation of the increase in gross national income and, as a result, consumption. This brings the following remarks:

Firstly, certain "technical" assumptions of the neoclassical approach should be regarded as anachronous in the light of the theoretical progress: homogeneity of the flowing capital (lack of distinction between the short-term and long-term capital), stability of this approach consisting in the analysis of the existing bilateral relations between countries, and, finally, the effectiveness of the markets and informational asymmetry (the latter is particularly criticised by Stiglitz).

Secondly, numerous economists raises doubts about financial globalisation as regards broadly understood effectiveness of capital allocation, especially beneficial distribution of risk and stabilisation (Greenwald \& Stiglitz, 2006; Reisen \& Soto, 2001). What is more, Lucas (1990) paid attention to the fact that capital flows mostly between highly developed countries and, later on, it turned out that against the neoclassical ideas - the capital is mostly transferred from less to more developed countries. In the years 1996-2006, the net outflow of capital from developing countries and countries during system transformation kept increasing, although the tendency was less visible in the latter. At the beginning of the new century, a group of countries with capital surplus was established, led by China. Paradoxically, as against the assumptions of the mainstream economy, the liberalisation of capital flow accelerated and caused the acquisition of funds to cover the deficit in the balance of payments easier, which was actually a huge step towards the economic breakdown.

Under conditions of erroneous deregulation and progressing liberalisation with the simultaneous lack of supervision and control, the so-called financialisation of the economy occurred - especially the American economy, which is to be understood as the strengthening of the role of the financial motivation, entities and financial markets both domestically and internationally. An increase in the share of the financial sector in the GDP occurred and at the same time, the financial market became autonomous towards the real zone by enhancing the risk level by financial engineering. The basis of its development was the assumption concerning the growing trend of variables, such as indices, asset valuation, GDP and, in this way, also the demand and constant inflow of money, which altogether accelerated the speculative turnover.

\section{Neoliberalism in the theoretical di- mension}

The neoliberal doctrine, encompassing specific ideas and notions about the economy, could become the original cause of the crisis only because of the fact that it was developed by tools of neoclassical economy, which has been criticised for years (it is worth remembering that also other, newer directions are included in the mainstream, such as behavioural economics, new institutional economics, experimental economics, etc. which not evoke sharp criticism). In general, the following main areas of criticism can be identified (Wojtyna, 2008: 12-13).

The first one stresses the weaknesses of economics as an instrument of scientific recognition, claiming that it is a "false" science preventing better understanding of economic society. As positive economics, it fails in the role of a tool, which explains facts and tendencies, which have already occurred, but also as a tool predicting upcoming events, especially the ones, which are important regionally or globally. Also, neoclassical economics viewed from the normative angle is assessed negatively. In this case, its excessive concentration on the problems of goods and money, and there is too little interest in the redistribution of wealth or ecology or the morality of people involved in the economic system.

Another area of criticism concerns the inadequacy of research methods: neoclassical economics (which continues to be called mainstream economics with the reservations submitted) is too theoretical and becomes similar to intellectual games, which do not lead to solving practical problems. Disputes revolve around the question whether economics should draw from methods typical of humanities or of natural sciences based on the application of mathematics. The superiority of 

within which rules of fight and cooperation apply differently from neoclassical ones. The majority of them are a common achievement of previously negotiating members of such a group.

An overview of opinions also shows a negative approach to the criticism of non-realistic assumptions lying at the base of neoclassical models. Hardt (2010, pp. 12-15) refers to the known Friedman theorem that the lack of realism in the assumptions concerning a given theory should not be a matter of concern for the theory itself, and, next, he supports this thesis using Solow's opinion: the complexity of reality necessitates the construction of simplified models. Compiling both of these positions, Hardt develops his own thought, which, however, takes a winding path, namely, that there does not exist an objective and aggregate measure accounting for the strength of the theory of economics. In consequence, the selection of defined assumptions of a model should be the researcher's pragmatic work, depending, for example, on the degree of precision, which they want to achieve for the explanation of a given fragment of reality. Hence, the conclusion about illegitimate comparison and evaluation of various economic models arises. However, one gets the impression that Hardt's digressions of being so general as they are a bit removed from the basic criticism of neoclassical economics, leaving out, among other things, the issues of cognitive reductionism and the lack of interaction between agents, which are of fundamental importance for macroeconomics. In other words, the aforementioned author does not define the borderlines, which should not be crossed while designing simplifying assumptions in models.

Thirdly, criticism towards excessive use of mathematical tools appears in the literature in connection with mainstream researchers striving for formal elegance of models, which can also be called an excess of ambition compared to the contents of research. The aforementioned criticism takes two forms: sharp and mild. In the first case, critics talk about confusion between "mathematical beauty" and the objective truth. It is not surprising, if one analyses Lawson's statement (2009, p. 765), who perceives the economy as a naturally closed set consisting of isolated elements, which prevents deductive, mathematical modelling. However, this observation is true only as regards certain group of models connected with Arrow-Debreu general equi- librium theory. It was based on twelve simplifying assumptions, among which the most important are those concerning the static and stationary character of the economy (a set of elements that are constant in time). However, if one considers other models, for example, the ones created within the framework of the game theory, they do not require such rigorous assumptions. This is just a step away from the mild form of criticism, in the light of which neoclassical researcher should strive for extending the mathematical tool so that it is possible to model various imperfections of markets and complex interactions of their agents. Such a procedure might make the mainstream economics closer to the trend of beneficial symbiosis of the technique with the contents of the research.

\section{Towards a new paradigm}

Hardt's conclusion about the impossibility of comparing and evaluating various economic models quoted above seems to confirm the lack of objective determinants of progress in economics. However, the case is not hopeless, the opinion that the following criteria determine the maturity of a theory predominates in the literature:

a) explaining social and economic phenomena in a way, which is convincing for the majority of researchers;

b) formulating possibly accurate forecasts;

c) creating theoretical bases for effective economic policy. If economics is to meet, in particular, the last criterion, it should undoubtedly be based on empirical research and progressing theory that requires also perfecting empirical research.

The increasing willingness among economists in recent years to face these criteria results in increased diversity and pluralism of tasks. These two notions are not identical as the pluralism of the theory concerns the judgemental evaluation of the situation in the area of theoretical diversity (Mäki, 1997, p. 39). In short, pluralism exists if there exists a positive evaluation of theoretical diversity, which enriches the cognitive possibilities of economics. However, a situation in which, despite the diversity of the theory, the pluralism is limited, as the conviction about the harmfulness of the diversification of studies predominates among numerous researchers - this was the case in the 1970s, when the opinion of intellectual perfection of the general equilibrium theory became consolidated. 

economics, leading to greater realism of economic research. The basic question concerns the actual mechanism of making decisions by people and explaining how individual decisions are transformed into the behaviour of markets and societies. Contemporary institutional economics creates a description of collective action of human entities, coordinated by institutional rules of the game and observed from the perspective of a company, state or a group of interests. However, from the point of view of research methodology, institutional economics is disappointing as it has not created a new analytical tool, which would be different from the orthodox one. Using tools of neoclassical economics and its deductive discipline, new institutionalism attempts to account for the operation and evolution of institutions in order to extend the scope of microeconomics and to increase its predictive power.

\section{Conclusions}

A comparative analysis of approaches to relations between the theory of economy and the economic development has shown the superiority of the historical approach, according to which causes of the contemporary crisis are much deeper than technical ones. Neoliberal ideology and the mainstream economics connected with it lie at the base of the crisis as they provided fuel for erroneous institutional policy initiating secondary causes of global breakdown, such as underdevelopment of global institutions and liberalisation of capital flow. Furthermore, the analysis of structure of dependency between these causes has proved that no crisis event was an accident, but a well thought-out effect of mutual, and sometimes cumulative, interactions between the aforementioned causes (the American economy, in which interaction between erroneous deregulation, quantitative loosening of monetary policy and global imbalance occurred, can be an example here).

The criticism of mainstream economics presented in the literature (for a long time) supported by the dishonourable role of this economics in the development and explosion of the crisis could signal the twilight of the traditional paradigm and the birth of a new one. This conclusion is partially right as despite the growing diversification and pluralism of research, it is easier to obtain a positive assessment of new ideas and research areas than a new methodology. Actually, apart from behavioural economics, none of the remaining inno- vative trends have not contributed in a significant way to the development of a new paradigm. Therefore, the situation of economics seems complex, increasing realism of the developed models will be certainly accompanied by a long-lasting process of modernisation of research methodology, which makes it possible to look into the future with moderate optimism, especially as regards the application value of economic theories.

\section{References}

1. Bauman, Z. (2000). Globalizacja. I co z tego dla ludzi wynika. Warsaw: Państwowy Instytut Wydawniczy.

2. Becker, G.S. (1990). Ekonomiczna teoria zachowań ludzkich. Warsaw: Wydawnictwo Naukowe PWN.

3. Bruni, L. \& Sugden, R. (2007). The Road Not Taken: How Psychology Was Removed from Economics, and How It Might Be Brought Back. The Economic Journal, 117(516), 137-162.

4. Claessens, S., Dell'Ariccia, G., Igan, D. \& Laeven, L. (2010). Lessons and Policy Implications from the Global Financial Crises. "IMF Working Paper" $\mathrm{WP} / 10 / 44$.

5. Colander, D., Goldberg, M., Haas, A. et al. (2009) The Financial Crises and the Systematic Failure of the Economics Profession. Critical Review, 21(2), 249-267.

6. Coyle, D. (2007). Soulful Science. What Economists Really Do and Why IT Matters. Princeton: Princeton University Press.

7. Eisenstadt, S.N. (2001). Modernization. In: J. Krieger (Ed.), The Oxford Companion to Politics of the World. (pp. 550-555 ). Oxford: Oxford University Press.

8. Fiedor, B., (2010). Kryzys gospodarczy a kryzys ekonomii jako nauki. Ekonomista, 4, 453-466.

9. Furubotn, E.G. \& Richter, R. (2000). Institutions and Economic Theory. The Contribution of the New Institutional Economics. Ann Arbor: The University of Michigan Press.

10. Greenwald, B. \& Stiglitz, J.E. (2006). Helping Infant Economics Grow. Foundations of Trade Policies for Developing Countries. American Economic Review, 96(2), 141-146.

11. Hardt, Ł. (2010). Criticizing the Critique. Some Methodological Insights into the Debate on the State of Economic Theory in the Face of the Post 
2008 Crises. Bank i Kredyt, 41(4), 7-22.

12. Harvey, D. (2005). A Brief History of Neoliberalism. Oxford: Oxford University Press.

13. Hayek, F.A. (1982). New Studies in Philosophy, Politics, Economics and the History of Ideas. London: Routledge \& Keagan Paul.

14. Kołodko, G.W. (2010), Neoliberalizm i światowy kryzys gospodarczy. Ekonomista, 1, 117-126.

15. Koronowski, A. (2009). Polityka pieniężna a kryzysy finansowe. Gospodarka Narodowa, 10, 3348.

16. Krugman, P. (2007). The Conscience of a Liberal. New York: Norton.

17. Lawson, T. (2009). The Current Economic Crises: Its Nature and the Course of Academic Economics. Cambridge Journal of Economics, 33(4), 759788.

18. Laeven, L. \& Valencia, F. (2010). Resolution of Banking Crises: The Good, the Bad, and the Ugly. "IMF Working Paper" WP/10/146.

19. Lucas, R.E. (1990). Why Doesn't Capital Flow from Rich to Poor Countries? American Economic Review, 80(2), 90-96.

20. Mäki, U. (1997). The One World and Many Theories. In: A. Salant and E. Scrapenti (Eds.), Pluralism in Economics. New Perspectives in History and Methodology. (pp. 28-51). Cheltenham: Edwar Elgar.

21. Morawski, W. (2010). Konfiguracje globalne. Struktury, agencje, instytucje. Warsaw: Wydawnictwo Naukowe PWN.

22. Reisen, H. \& Soto, M. (2001). Which Types of Capital Inflows Foster Developing-Country Growth?. International Finance, 4(1), 1-14.

23. Rosati, D. (2009). Przyczyny i mechanizm kryzysu finansowego w USA. Ekonomista, 3, 316-351.

24. Rybiński, K. (2007). Globalizacja $w$ trzech odsłonach. Offshoring-globalne nierównowagi-polityka pieniężna. Warsaw: Difin SA.

25. Sławiński, A. (2007). Banki centralne a globalizacja. In: W. Małecki (Ed.), Globalizacja rynków finansowych - implikacje dla Polski. (pp. 65-84) Warsaw: Vizja Press \& IT.

26. Szymański, W. (2009). Kryzys globalny. Pierwsze przybliżenie. Warsaw: Difin SA.

27. Szyszka, A. (2009). Behawioralne aspekty kryzysu finansowego. Bank i Kredyt, 40(4), 5-30.

28. Taylor, J.B. (2009). Getting Off Track. How Govern- ment Actions and Interventions Caused, Prolonged, and Worsened the Financial Crises. Stanford: Hoover Institution Press, Stanford University.

29. Wojtyna, A. (2008). Współczesna ekonomia kontynuacja czy poszukiwanie paradygmatu? Ekonomista, 1, 9-32.

30. Żyżyński, J. (2009). Neoliberalizm jako strukturalna przyczyna kryzysu a poszukiwanie dróg naprawy. Ekonomista, 2, 165-187. 